\title{
STUDY ON COMPRESSIVE BEHAVIOR AND FAILURE MECHANISM OF A COMPOSITE ENERGY-SAVING WALL MADE OF RECYCLED-CONCRETE BRICKS
}

\author{
ŠTUDIJA MEHANIZMOV POŠKODB IN PORUŠITVE ZARADI \\ TLAČNIH OBREMENITEV KOMPOZITNIH \\ ENERGIJSKO-IZOLACIJSKIH STEN, IZDELANIH IZ OPEK NA \\ OSNOVI RECIKLIRANEGA BETONA
}

\author{
Jianhua Li ${ }^{1}$, Wenjing Chen ${ }^{1}$, Renyan Zhu ${ }^{1}$, Yan Liu ${ }^{2}$, Zhongyi Zhou ${ }^{3 *}$ \\ 1 Jiyang College of Zhejiang A\&F University, 77 Puyang Road, Jiyang Street, Shaoxing, Zhuji 311800, Zhejiang, China \\ ${ }^{2}$ School of Architectural Engineering, North China University of Science and Technology, 21 Bohai Road, Caofeidian Xincheng District, \\ Tangshan 063210, Hebei, China \\ ${ }^{3}$ Key Laboratory of Earthquake Engineering and Engineering Vibration, Institute of Engineering Mechanics, China Earthquake Administration, \\ 29 Xuefu Road, Nangang District, Harbin 150080, Heilongjiang, China
}

Prejem rokopisa - received: 2018-09-26; sprejem za objavo - accepted for publication: 2018-12-17

doi: 10.17222/mit.2018.209

\begin{abstract}
Axial compression tests were conducted to analyze and compare the compressive behavior and failure mechanism of four wall specimens. The four wall specimens were: (1) a recycled-concrete brick wall; (2) a composite wall of recycled-concrete brick wall with a fly-ash block, (3) a composite wall of recycled-concrete bricks with an outside EPS insulation wall, (4) a composite wall of recycled-concrete bricks with an EPS insulation board. The compressive strength of all four specimens increased obviously with an increase in their thermal insulation. The bearing capacity and strain of the recycled-concrete brick wall with a fly-ash block showed an obvious increase compared with the recycled-concrete brick wall. In addition, its yield load and ductility significantly improved and the brittle failure mode clearly changed. Based on the experimental observation and failure-mechanism analysis of the composite thermal-insulation wall made of recycled-concrete bricks, a theoretical calculation model was established and the calculation formula for the compressive bearing capacity was suggested. Compared with the test results, the calculation formula for the bearing capacity was correct and reasonable. Therefore, it can be used in the design of composite energy-saving walls.

Keywords: recycled-concrete brick masonry, axial compression, experimental study, theoretical analysis

Avtorji so izvajali aksialne tlačne preizkuse, da bi analizirali in primerjali obnašanje pod tlačno obremenitvijo in mehanizme poškodb na štirih vzorcih (stenah). Vzorci so bili pripravljeni iz: (1) recikliranih betonskih opek; (2) kompozitnih betonskih sten iz recikliranega betona, napolnjenih z bloki iz dimniškega pepela; (3) kompozitnih sten iz recikliranih betonskih opek in zunanje EPS izolacije ter (4) kompozitnih sten iz recikliranih betonskih opek, napolnjenih s ploščami iz EPS izolacije. Tlačna trdnost vseh štirih vzorcev sten je vidno naraščala $\mathrm{z}$ naraščanjem njihove toplotne izolacije. Nosilnost in deformacija recikliranih betonskih opek, napolnjenih $\mathrm{z}$ dimniškim pepelom, je vidno narasla $\mathrm{v}$ primerjavi $\mathrm{z}$ reciklirano betonsko steno. Plastičnost in duktilnost sta se vidno izboljšali in krhka narava preloma se je spremenila. Na osnovi eksperimentalnih opazovanj in analize mehanizmov poškodb kompozitnih termičnih izolacijskih sten so avtorji izdelali teoretični model za izračun tlačne trdnosti oz. nosilnosti preiskovanih materialov. Primerjava z rezultati eksperimentov je potrdila sprejemljivo ujemanje izračunov nosilnosti na osnovi razvite enačbe. Tako se le-ta lahko uporabi za dizajn kompozitnih energijsko absorpcijskih sten.

Ključne besede: zidanje z reciklirano betonsko opeko, aksialne tlačne obremenitve, eksperimentalna študija, teoretična analiza
\end{abstract}

\section{INTRODUCTION}

The external wall of a masonry structure is an important part of a building. It not only bears the vertical loads from the roof, but also provides heat insulation, resistance to horizontal earthquakes, storms, etc. ${ }^{1-3}$ Due to a rapid industrial development and an urgent need for energy-saving conservation programs, the exterior walls of masonry structures were continually advanced with respect to energy saving, and profitable, compound and local materials. Clay bricks are not ideal for such functions as they are fired at high temperatures. Moreover, they create waste and might destroy farmlands. ${ }^{4}$ There-

*Corresponding author e-mail:

zzyhui@163.com fore, it is important that new recycled green building materials are used in place of clay bricks. Recycled-concrete bricks, which are made of construction-waste coarse aggregate and fine aggregate, are proposed as an alternative, replacing clay bricks. ${ }^{5}$ Fly-ash blocks made of fly ash, slag, sand or other production wastes are green energy-saving materials with many advantages. First, these materials are small in volume and have the ability to preserve heat. They also allow thermal insulation, energy saving, sound insulation and excellent processing; hence, they are ideal for use as building materials. ${ }^{6}$ The properties of recycled-concrete bricks are similar to those of clay bricks. Therefore, recycled concrete bricks can save resources and replace clay bricks. Besides, fly-ash blocks have a larger strain value 
compared with the recycled-concrete brick masonry, and better heat-preservation performance. ${ }^{7}$ Combining fly-ash blocks with the recycled-concrete brick masonry can transform the mechanical properties of the recycledconcrete brick masonry, which can further improve the heat-preservation performance. The combination of an EPS insulation board and the recycled-concrete brick masonry can also provide for a better thermal-insulation performance. A wall of recycled-concrete bricks, a fly-ash block and an EPS insulation board is the modern type of ecological wall with respect to both the strain and energy-saving factors. Therefore, it facilitates convenient construction and good insulation effects compared with other materials.

The thermal performance of a composite wall was studied by other researchers ${ }^{8,9}$ and their results showed that the thermal performance of a wall is greatly improved when bricks of fly ash and an EPS insulation board are used. Furthermore, the mechanical property of a composite wall is also important. Therefore, the axialcompression performance of a new wall is studied in this research. The axial-compression capacities of the new wall and the present wall are analyzed and compared. Further, the influence of a fly-ash block on the compression performance of a wall is also investigated. From this investigation, the performance and failure mechanisms of a fly-ash block and brick are analyzed in detail. Lastly, the expression for the bearing capacity of a composite wall is proposed.

\section{MATERIALS AND METHODS}

\subsection{Specimen design and production}

The experiment involved a design and production of specimens, meeting the requirements of 'The standard test method for the basic mechanical properties of masonry' (GB/T 50129-2011). ${ }^{10}$ Four test pieces were prepared for the experiment. Test piece 1 was a $240-\mathrm{mm}$ recycled-concrete brick wall (RBM) with a width of 370 $\mathrm{mm}$ and a height of $720 \mathrm{~mm}$. Test piece 2 was a composite wall consisting of $115-\mathrm{mm}$ recycled-concrete bricks on both sides and a 120-mm fly-ash block in between (RFRM), with a width of $370 \mathrm{~mm}$ and a height of $720 \mathrm{~mm}$. There was about 10-mm masonry mortar between the recycled-concrete brick wall and the fly-ash block, set up as a Z-shaped bar along the height of every $240 \mathrm{~mm}$. Test piece 3 was a composite wall with $115-\mathrm{mm}$ recycled-concrete bricks on both sides and a 60-mm EPS insulation board in between (RERM), with a width of $370 \mathrm{~mm}$ and a height of $720 \mathrm{~mm}$. There was also about 10 -mm-thick masonry mortar between the recycled-concrete brick wall and the fly-ash block, set up as a Z-shaped bar along the height of every $240 \mathrm{~mm}$. Test piece 4 was a composite wall consisting of $240-\mathrm{mm}$ concrete brick masonry, a 60-mm EPS insulation board (REM) and a 20-mm cement-mortar steel-wire mesh on the outside, with the three parts being connected by plastic expansion bolts. The width of the specimen was about $370 \mathrm{~mm}$ while the height was about $720 \mathrm{~mm}$. A concrete steel-wire mesh layer with a thickness of 30 $\mathrm{mm}$ was arranged to avoid local compression damages at the upper and the lower ends of the specimen.

The masonry material consisted of the MU10 clay bricks, recycled-concrete bricks, M7.5 mortar and a MU2.5 fly-ash block. The opening of the steel mesh on the protective layer of the REM specimen was approximately $10 \mathrm{~mm} \times 10 \mathrm{~mm}$, while the diameter was $0.6 \mathrm{~mm}$. The concrete design strength of the upper and the lower concrete steel-wire mesh layer was C40. The specimen was constructed on a smooth area. The initial step involved cementing the concrete steel-wire mesh layer at the bottom. After being hardened, the masonrywall specimen was uniformly constructed by a middlelevel masonry worker. Then, the upper concrete
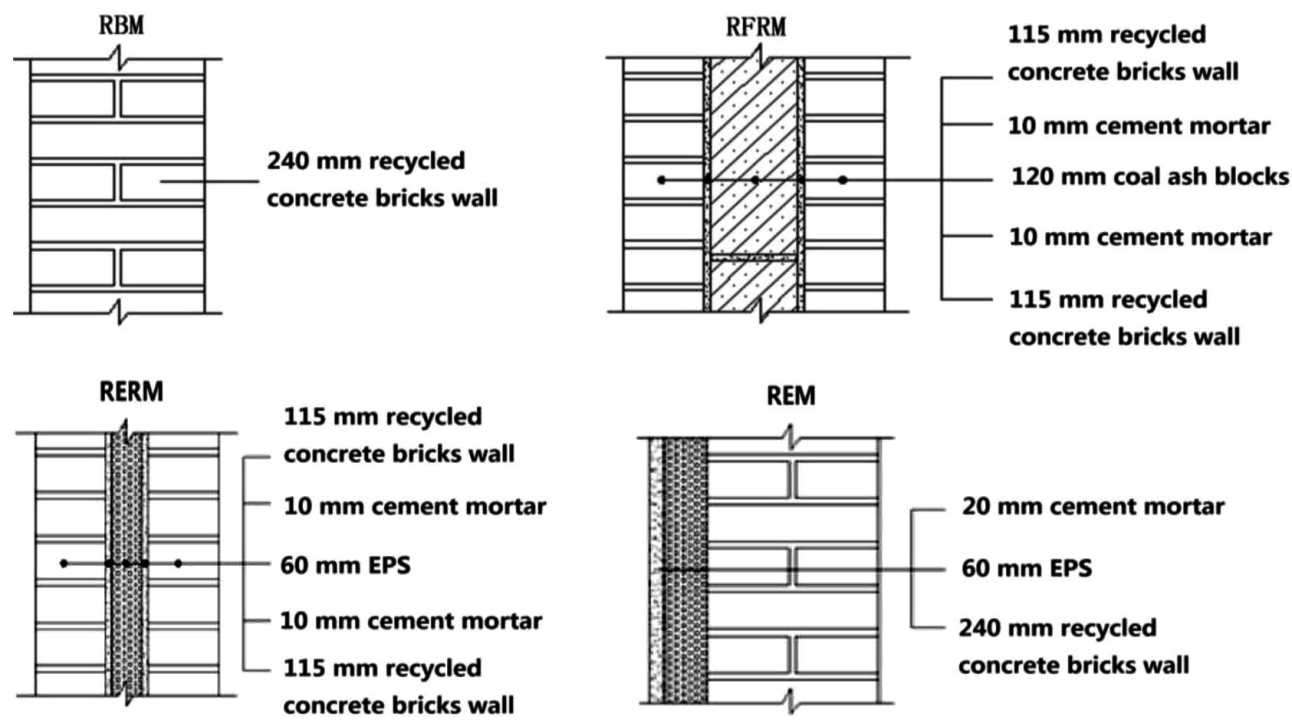

Figure 1: Specimen structure type diagram 
steel-wire mesh layer was made. After the completion of the construction, the test was started after $28 \mathrm{~d}$ of maintenance. The specific structure of each specimen is illustrated in Figure 1.

\subsection{Material performance index}

In accordance with the 'Test methods for wall bricks' (GB/T 2542-2003), the design and compressive strength test of the specimens of a clay brick and recycled-concrete brick were performed. In accordance with the national standard 'Test methods for performance of autoclaved aerated concrete' (GB/T 11969-2008), fly-ash block cubes and prisms were also designed and tested.

The primary-mechanical-property specimens of a clay brick, recycled-concrete brick and masonry mortar were made in the construction process. Then the compressive strength was measured and recorded. The compressive strength of the clay brick was found to be 11.05 $\mathrm{MPa}$, and the compressive strength of the recycled-concrete brick was 14.85 $\mathrm{MPa}$. Besides, the compressive strength of the fly-ash block was found to be $2.35 \mathrm{MPa}$ while the compressive strength of the mortar was found to be $8.37 \mathrm{MPa}$. Finally, the compressive strength of the EPS insulation board was found to be $0.3 \mathrm{MPa}$.

\subsection{Loading scheme and test procedure}

The test method was accurately executed as per the national 'Standard test method for the basic mechanical properties of masonry' (GB/T50129-2011). During the test, the cracking load and the ultimate load of the specimens were primarily tested. The failure process and the final failure mode were observed during the whole process. The damage processes and compressive-bearing capacities of the specimens were also compared with each other.

\section{RESULTS AND DISCUSSION}

\subsection{Axial load/strain curve}

The axial load/strain curves were compared and analyzed with respect to the mechanical properties of various thermal-insulation materials and their component types; the bearing capacities of the specimens were analyzed using the axial load/strain curves of the specimens.

Figure 2a demonstrates that the bearing capacity and strain of the wall exhibited a larger increase after the addition of fly ash to the recycled-concrete brickmasonry block. Consequently, the yield load as well as the ductility also increased. At the same time, deformation properties of the fly-ash block greatly improved the recycled-concrete brick-masonry brittle failure, as they can improve the bearing capacity of the whole specimen and its plastic-deformation ability. Figure 2b shows that the bearing capacity and strain curves of the
EPS insulation plate between the recycled-concrete bricks and of the recycled-concrete brick were somewhat similar. The EPS bearing capacity was, however, slightly higher than that of the recycled-concrete brick. The recycled-concrete brick with the EPS insulation board and composite cement-mortar steel-wire mesh, as well as the recycled-concrete brick with the EPS insulation plate had similar bearing capacities when compared with the other two samples with a high-cement-mortar steel-wire mesh used for enhancing their overall bearing capacity. Figure 2c indicates that the recycled-concrete brick masonry with a fly-ash block exhibited higher bearing stress and strain when compared with those of the recycled-concrete brick and the recycled-concrete brick with the EPS insulation board. Fly-ash blocks can con-
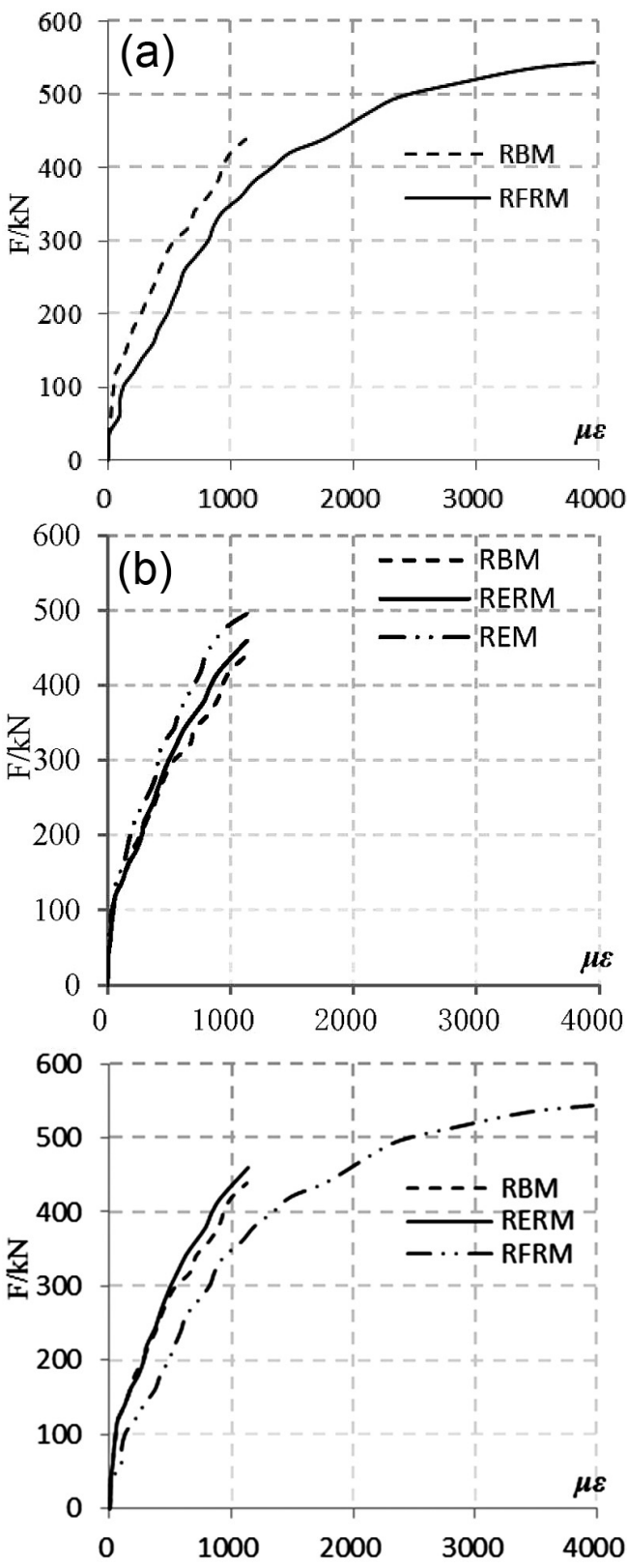

Figure 2: Comparison of axial load/strain curves 


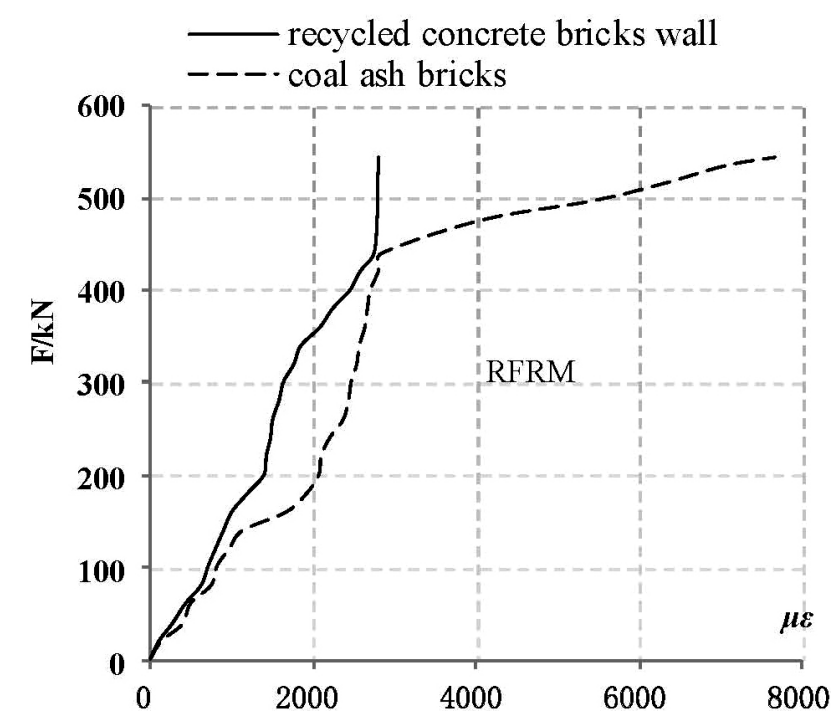

Figure 3: Curves of axial load/strain

siderably enhance the bearing capacity of the recycledconcrete brick masonry together with the deformation performance, but have little impact on the bearing capacity and deformation of the recycled-concrete bricks including the EPS insulation board.

Figure 3 shows the strain curves of the regeneratedconcrete brick and fly-ash block under the action of load. By analyzing the causes of damage and revealing the common mechanism of actions, it is possible to provide the basis for design calculations.

According to the load/strain curve, crack observation of the recycled-concrete brick and the under-load fly-ash block, destruction processes went through three distinct stages: (1) Prior to the cracking of the mortar between the fly-ash block and the recycled-concrete brick, the load/strain curve of the fly-ash block and the bricks on both sides was typically concurrent. Moreover, the deformation of the two was found to be consistent. A further analysis of the elastic modulus of the two revealed that, before the cracking, the load of the recycledconcrete brick masonry was larger when compared with the intermediate fly-ash block. Accordingly, the mortar restrained the deformation of the other two elements. (2) After the cracking of the bonding mortar, the internal force between the recycled-concrete brick masonry and the fly-ash block was redistributed. In the absence of the fly-ash brick and mortar constraints, the load of the recycled-concrete brick rose rapidly. However, the strain was found to increase slowly. With a continued increase of the applied load, load and strain curve slopes became larger. In the fly-ash blocks, in the case of the loss of recycled-concrete brick-masonry constraints, the strain first grew up considerably fast, followed by the load/strain curve-slope decreasing. The strain of the recycled-concrete brick was observed to be smaller than that of the fly-ash block. Since the elastic modulus of the brick was larger than that of the fly-ash block, the load was mainly borne by the recycled-concrete brick masonry. (3) As the load continued to increase, the strain of the brickwork was also almost constant, while the strain of the fly-ash block was rapidly increasing. As per the analysis of the perceived phenomena, the crack of the recycled-concrete brick masonry increased. The fly-ash block increased to a certain extent, then started to change the characteristics of the brittle failure of the recycled-concrete brick masonry to a certain extent. Therefore, the bearing capacity of the recycled-concrete brick masonry was given full play.

\subsection{Bearing-capacity analysis}

The relative values of the crack load and final load of the specimens are summarized in Table $\mathbf{1}$ below:

Table 1: Test pieces, their cracking loads, limit loads and comparison

\begin{tabular}{|c|c|c|c|c|c|}
\hline $\begin{array}{c}\text { Specimen } \\
\text { number }\end{array}$ & $F_{\mathrm{s}}(\mathrm{kN})$ & $F_{\mathrm{c}}(\mathrm{kN})$ & $F_{\mathrm{u}}(\mathrm{kN})$ & $F_{\mathrm{c}} / F_{\mathrm{u}}$ & $\begin{array}{c}F_{\mathrm{u}} \\
\text { relative }\end{array}$ \\
\hline RBM & - & 277.65 & 439.13 & 0.63 & 1 \\
\hline RFRM & 121.35 & 344.33 & 544.32 & 0.63 & 1.24 \\
\hline RERM & 145.44 & 302.15 & 460.17 & 0.66 & 1.05 \\
\hline REM & 142.37 & 320.08 & 500.26 & 0.64 & 1.14 \\
\hline
\end{tabular}

Here, $F_{\mathrm{s}}$ denotes the cracking load of the adhesive mortar between the thermal insulation material and the brick masonry; $F_{\mathrm{c}}$ represents the crack load of the brick-masonry specimen, it is the first crack load of the brick masonry; $F_{\mathrm{u}}$ stands for the ultimate load of the specimen, it is the maximum value of the test load.

From Table 1, the following can be observed: (1) The fly-ash block can enhance the bearing capacity of the specimen. The proportion of the ultimate or final load of the recycled-concrete brick increased by about $24 \%$; the ultimate bearing capacity of the EPS insulation board in the middle of the recycled-concrete brick wall increased by $5 \%$; the ultimate load capacity of the recycled-concrete bricks outside the EPS insulation board with the composite cement-mortar wire mesh also increased by $14 \%$. (2) For the specimen with the added fly-ash block and EPS insulation board, the cracking loads of the mortar were small. However, the brick-masonry cracking load was improved while the ultimate load was improved; as a result, the cement-mortar bonding layer, fly-ash block and EPS insulation board helped to enhance the bearing capacity of the specimen.

\section{CALCULATION MODEL OF THE COMPRES- SIVE COMPOSITE THERMAL-INSULATION WALL}

\subsection{Calculation model of the compressive bearing ca- pacity}

Through the analysis of the stress state of the composite wall specimen including concrete bricks, the fly-ash block and composite insulation, it is observable that when the entire specimen attains the ultimate bear- 
ing capacity, the bearing capacity applies to the brick masonry, fly-ash block and the stick. The equilibrium equation of the force is applied to the mortar to acquire its ultimate bearing capacity:

$$
N=f_{\mathrm{m}} A_{\mathrm{m}}+f_{\mathrm{f}} A_{\mathrm{f}}+f_{\mathrm{s}} A_{\mathrm{s}}
$$

where $N_{\mathrm{m}}$ represents the compressive bearing capacity of the brick masonry; $N_{\mathrm{f}}$ denotes the compressive bearing capacity of the insulating material; $N_{\mathrm{s}}$ stands for the compressive bearing capacity of the bonding mortar; $f_{\mathrm{m}}$ denotes the stress of the brick masonry under axial compression; $f_{\mathrm{f}}$ represents the axial compressive stress of the thermal-insulation material; $f_{\mathrm{s}}$ stands for the stress of the axial compression of the mortar; $A_{\mathrm{m}}$ denotes the compression area of the brick masonry; $A_{\mathrm{f}}$ is the insulation-material pressure area; and $A_{\mathrm{s}}$ represents the adhesive-mortar pressure area.

In accordance with the test results and references, ${ }^{11}$ the stability of a specimen is considered. The calculation for the composite insulation wall can be expressed as follows:

$$
N=\varphi\left(f_{\mathrm{m}} A_{\mathrm{m}}+f_{\mathrm{f}} A_{\mathrm{f}}+f_{\mathrm{s}} A_{\mathrm{s}}\right)
$$

Where $\varphi$ represents the stability coefficient of the masonry according to 'Masonry-structure design specifications'.

\subsection{Validation of the compressive bearing-capacity mo- del}

Formula (2) of the bearing-capacity calculation model inferred from the above theory is applicable to the computation of the four types of wall specimens.

Based on the test results and provisions of the national norms 'Masonry-structure design specifications' (GB 50003-2011), the strengths of the specimens, clay-brick masonry, $\mathrm{CBM}$ and recycled brick masonry (RBM) might be computed or measured as per the following formula:

$$
f_{\mathrm{m}}=k_{1} f_{1}^{\alpha}\left(1+0.007 f_{2}\right) k_{2}
$$

where $f_{\mathrm{m}}$ represents the average compressive strength of the masonry; $f_{1}$ stands for the compressive-strength level or average; $f_{2}$ denotes the average compressive strength of the mortar; $k_{1}$ indicates the parameters related to the block class; $\alpha$ signifies the parameters related to the block type and masonry category; and $k_{2}$ refers to the correction coefficient of the mortar strength or masonry compressive strength. This result is obtained by substituting the computed material-strength value in Equation (3) and assuming that $k_{1}=0.78, \alpha=0.5, k_{2}=1.0$.

For the recycled-concrete brick masonry, the formula for its bearing capacity can be expressed as follows:

$$
N_{\mathrm{m}}=f_{\mathrm{m}} A_{\mathrm{m}}
$$

On the other hand, the compressive strength of the fly-ash block can be determined by the results from the literature. ${ }^{12}$ Combined with the compressive strength of the fly-ash block, the computation of the formula for the bearing capacity can be expressed as follows:

$$
N_{\mathrm{f}}=f_{\mathrm{f}} A_{\mathrm{f}}
$$

For the bonding mortar and EPS insulation board, in the vertical direction and for a single material, the bearing capacity might be directly expressed by the product of the compressive strength and cross-sectional area.

In accordance with Formula (2) and the above calculation method, the relationship between the computed values of the compressive strength and its measured values is illustrated in Table 2.

Table 2: Comparison between calculated values and measured values of the ultimate load

\begin{tabular}{|c|c|c|c|}
\hline Specimen & $\begin{array}{c}\text { Measured limit } \\
\text { load } \\
\left(F_{\mathrm{T}}\right)(\mathrm{kN})\end{array}$ & $\begin{array}{c}\text { Calculated } \\
\text { ultimate load } \\
\left(F_{\mathrm{E}}\right)(\mathrm{kN})\end{array}$ & $F_{\mathrm{T}} / F_{\mathrm{E}}$ \\
\hline RBM & 439.13 & 423.03 & 1.04 \\
\hline RFRM & 544.32 & 525.11 & 1.04 \\
\hline RERM & 460.17 & 470.45 & 0.98 \\
\hline REM & 500.26 & 487.54 & 1.03 \\
\hline
\end{tabular}

The calculation results indicate that the error is within $5 \%$. In addition, when calculating the bearing capacity for the brick composite insulation wall, the measured value of the ultimate load of the composite insulation wall is accurate and reasonable.

\section{CONCLUSIONS}

In summary, through the research and theory analyzing four types of wall specimens under axial compression, it was evident that the bearing capacity of the recycled-concrete brick masonry was obviously enhanced after an addition of an insulation material, especially the one that included a fly-ash block. Meanwhile, the strain also considerably increased with the yield load. Moreover, ductility also improved significantly, while the brittle failure of the specimen changed. Based on an analysis of the destructive process and mechanism of a composite including concrete bricks and an insulation wall, a bearing-capacity model was finally established. Further verification was also performed to obtain an accurate and reasonable comparison between the theoretical calculation and test values. Therefore, it would be applicable for similar wall designs.

\section{Acknowledgements}

This research was supported by the Scientific Research Fund of the Institute of Engineering Mechanics, China Earthquake Administration (Grant no. 2016B10) and the talent project of the Jiyang College, Zhejiang Agriculture and Forestry University, China (JYRC201605, JYRC201604). The samples were tested at the Beijing University of Technology of China. 


\section{J. LI et al.: STUDY ON COMPRESSIVE BEHAVIOR AND FAILURE MECHANISM ...}

\section{REFERENCES}

${ }^{1}$ Q. Chen, B. Li, X. Liu, An experimental evaluation of the living wall system in hot and humid climate, Energ. Buildings, 61 (2013), 298-307, doi:10.1016/j.enbuild.2013.02.030

${ }^{2}$ D. Jian, Seismic analysis of external insulation system installed on exterior wall under frequently occurred earthquake, Journal of Nanjing University of Science and Technology, 4 (2012) 033, doi:1005-9830(2012)04-0734-05

${ }^{3} \mathrm{M}$. Ozel, Effect of insulation location on dynamic heat-transfer characteristics of building external walls and optimization of insulation thickness, Energ. Buildings, 72 (2014), 288-295, doi:10.1016/ j.enbuild.2013.11.015

${ }^{4}$ T. Karthik, R. Rathinamoorthy, Recycling and reuse of textile effluent sludge, Environmental implications of recycling and recycled products, Springer, Singapore 2015, 213-258

${ }^{5}$ Z. Ge, Z. Gao, R. Sun, L. Zheng, Mix design of concrete with recycled clay-brick powder using the orthogonal design method, Constr. Build. Mater., 31 (2012), 289-293, doi:10.1016/ j.conbuildmat.2012.01.002

${ }^{6} \mathrm{P}$. Turgut, Fly ash block containing limestone and glass powder wastes, KSCE J. Civ. Eng., 17 (2013), 1425-1431, doi:10.1007/ s12205-013-0280-6
${ }^{7}$ J. Wu, G. L. Bai, H. Y. Zhao, X. Li, Mechanical and thermal tests of an innovative environment-friendly hollow block as self-insulation wall materials, Constr. Build. Mater., 93 (2015), 342-349, doi:10.1016/j.conbuildmat.2015.06.003

${ }^{8} \mathrm{~J} . \mathrm{Li}, \mathrm{W}$. Cao, The heat transfer coefficient of recycled concrete bricks combination with EPS insulation board wall, Math. Probl. Eng., 2015 (2015), doi:10.1155/2015/695962

${ }^{9}$ J. Li, W. Cao, G. Chen, The heat transfer coefficient of new construction - Brick masonry with fly ash blocks, Energy, 86 (2015), 240-246, doi:10.1016/j.energy.2015.04.028

${ }^{10} \mathrm{~GB} / \mathrm{T}$ 50129-2011:2011 Standard for test method of basic mechanics properties of masonry, Ministry of Housing and Urban-Rural Development of the People's Republic of China, China Construction Industry Press, Beijing

${ }^{11}$ Y. Cai, Z. Yu, Experimental investigation on brick masonry strengthened with high performance mortar and steel wire mesh, Journal of Railway Science and Engineering, 5 (2007), 1-5, doi:1672-7029 (2007)05-0001- 05

${ }^{12}$ J. Wang, D. Weng, M. Yang, Analysis of mechanical properties of autoclaved aerated concrete masonry, Journal of Xiamen University of Technology, 1 (2012), 79-82, doi:1673-4432(2012)01-0079-04 